\title{
KOMUNIKASI ORANGTUA DAN ANAK (STUDI KASUS PADA KELUARGA BEDA AGAMA)
}

\author{
MASHFIYATUL ASMAAI \\ Universitas Islam Negeri (UIN) Sunan Ampel Surabaya \\ Email : mashfiyatul_asmaai@yahoo.com
}

\begin{abstract}
:
Communication has a very important role in every relationship, one of which is a family relationship. Both in families who live in one religion or who live with different religions. Differences in beliefs do not have such a large impact on the harmony of a family if previously the family already had a commitment to respect each other's beliefs. It is indeed more difficult to maintain harmonious relationships based on religious differences compared to relationships with one religion. But in a family, if parents already trust and respect each other in matters of religion, then parents will also give confidence to their children to choose their own religion so as not to interfere with the establishment of communication between family members. The frequency with which communication occurs between parents and children often affects the emotional closeness between parent and child. The more often communication occurs within a family, the familial relationship will be more intimate and bring about mutual openness among family members. Because of the communication style given by parents to children can have an influence on the development patterns of children's thinking.
\end{abstract}

Keywords : communication; parents; children; different religions

\section{PENDAHULUAN}

Orangtua dan anak adalah komponen dari sebuah organisasi yang bernama keluarga. Setiap keluarga menginginkan keluarga yang bahagia, saling mencintai baik secara lahir dan batin. Orang tua sebagai pimpinan bertanggung jawab terhadap pertumbuhan dan perkembangan anak. Salah satu penyebab terhambatnya karakter anak yaitu keluarga yang broken home. Penerapan pola pendidikan yang tidak sesuai, juga bisa beresiko fatal terhadap perkembangan karakter anak. Maka akan berdampak pada sikap dan perilaku anak tidak sesuai dengan norma yang berlaku dimasyarakat. Dengan demikian, orang tua menjadi faktor utama yang akan dipersalahkan. Sejak dilahirkan, lingkungan pertama yang dikenal seorang anak dalam kehidupannya adalah orang tua, maka orang tua dan keluarga memiliki peranan paling besar terhadap perkembangan moral anak. ${ }^{1}$

Jika lingkungan seorang anak bersikap tidak peduli dan apatis terhadap norma, maka seorang anak dapat dipastikan tidak mengerti dan acuh terhadap

${ }^{1}$ Singgih D. Gunarsa dan Ny. Y. Singgih D. Gunarsa, Psikologi Perkembangan Anak dan Remaja (Jakarta: PT BPK Gunung Mulia, 2006), hlm60 
norma baik norma agama, norma sosial maupun norma-norma yang lain. ${ }^{2}$ Orang tua harus sudah mengajarkan nilai-nilai agama pada anak dalam usia yang masih sangat kecil yaitu 0-3 tahun, karena perilaku beragama adalah sesuatu yang harus dibiasakan dan ditanamkan sejak dini kepada anak sebagai dasar atau pondasi untuk melakukan segala hal. Pendidikan nilai-nilai tentang agama juga akan membantu anak untuk memelihara fitrahnya sebagai manusia, memelihara jiwa, memelihara akal, memelihara keturunan dan memelihara serta menjaga diri dari mengikuti hawa nafsu. ${ }^{3}$

Orang tua perlu memperhatikan metode-metode memberi komunikasi efektif dan bimbingan kepada anak. Ketika orang tua hanya mengandalkan lembaga pendidikan untuk mengawasi perkembangan anak akan memunculkan permasalahan yang lain. Sehubungan dengan pentingnya peran orang tua dalam memberikan pendidikan baik secara moral maupun pendidikan keagamaan maka penting pula diperhatikan keyakinan agama yang dimiliki orang tuanya.

Setiap agama apapun telah mengatur hal yang bersangkutan dengan pernikahan, tak terkecuali agama islam. Dalam agama islam pernikahan selain dimaksudkan untuk memperbanyak keturunan pernikahan juga dimaksudkan untuk melahirkan kelompok kecil dalam keluarga yang dilandasi dengan ruh sakinah, mawadah dan warahmah. seperti yang termaktub dalam kita al qur'an :

"Dan diantara tanda-tanda kekuasaanya ialah dia menciptakan untukmu pasangan hidup dari jenis kamu sendiri, supaya kamu cenderung dan merasa tentram kepadanya, dan dijadikannya diantara kamu rasa kasih sayang ${ }^{4,}$

Keterangan di atas terlihat bahwa dalam islam sendiri seorang diperbolehkan menikah apabila keduanya satu keyakinan, artinya pernikahan dianggap sah apabila sama sama beragama islam dan tidak sah bila salah satunya telah murtad. Sedangkan dalam Negara sendiri dasar hukum perkawinan antar agamadalam Undang-undang perkawinan UUP telah dijelaskan pada pasal 2ayat (1) menjelaskan "bahwa perkawinan adalah sah apabiladilakukan menurut hukum masing-masing agamanya dan kepercayaannya. disamping itu pasal 8 mengatakan bahwa perkawinan itu dilarang apabila yangbersangkutan mempunayi hubungan yang oleh agamnya atau-aturan yang lain terlarang kawin.Dalam Kompilasi Hukum Islam (KHI) masalah ini diatur hanyadalam dua pasal yang termasuk bab VI tentang larangan kawin, yaitupada pasal 40 sub c

\footnotetext{
${ }^{2}$ Syamsu Yusuf dan A. Juntika Nurihsan, Landasan BIMBINGAN\& KONSELING (Bandung: PT Remaja Rosdakarya Offset, 2009),hlm135

${ }^{3}$ Syamsu Yusuf dan A. Juntika Nurihsan, Landasan BIMBINGAN\& KONSELING (Bandung: PT Remaja Rosdakarya Offset, 2009),hlm138

${ }^{4}$ Q.S. Ar Rumm :21
} 
dan pasal 44, selengkapnya sebagai berkut :Pasal 40; Dilarang melangsungkan perkawinan antara pria dengan seorang wanita karena keadaan tertentu: a) Seorang wanita yang tidak beragama Islam, Pasal 44; seorang wanita Islam dilarang melangsungkan perkawinan denganpria yang tidak beragama Islam.

Namun seiring dengan semakin dinamisnya suatu kehidupan, maka semakin mengikisnya pula norma norma agama yang telah dianut. Telah banyak dijumpai sepasang suami istri yang memutuskan untuk tetap menikah meskipun diantara keduanya memiliki perbedaan agama. Banyak pula kasus dimana seorang pasangan yang berbeda agama tersebut masuk dalam agama pasanganya hanya sebagai pemenuhan syarat dalam pernikahan namun setelah menikah dia kembali ke keyakinannya semula. Adanya kasus yang demikian memungkinkan akan memimbulkan dampak bagi hubungan dalam keluarga tersebut terutama bagi anaknya.

Dalam penelitian ini, peneliti ingin memahami dan mendeskripsikan peran komunikasi dalam hubungan anggota keluarga yang berbeda agama, bentuk bimbingan dan sistem pendidikan yang diberikan oleh orang tua beda agama terhadap perkembangan anak, masalah yang sering muncul dalam hubungan komunikasi anggota keluarga berbeda agama dan usaha orang tua dalam mengatasi masalah komunikasi dengan anak yang disebabkan oleh perbedaan latar belakang agama.

\section{TINJAUAN TEORITIS}

Komunikasi menurut McCroskey menyatakan bahwa aprehensi komunikasi itu muncul pada manusia karena pengaruh suasana komunikasi di rumahnya. Dinyatakan bahwa faktor-faktor lingkungan rumah, seperti jumlah percakapan dengan anggota keluarga dan gaya interaksi anak-orang tua akan mempengaruhi perilaku komunikasi anak. Ini menunjukan bahwa lingkungan keluarga menjadi penentu penting ada tidaknya ". Komunikasi memegang peran penting dalam kehidupan, tanpa komunikasi kita tidak dapat hidup, karena kebutuhan kita terpenuhi melalui komunikasi. ${ }^{5}$ Salah satu bentuk komunikasi adalah komunikasi dalam keluarga. Komunikasi sangat dibutuhkan antar anggota keluarga untuk membicarakan masalah-masalah mengenai keberlangsungan kehidupan keluarga tersebut, mulai dari hal terkecil hingga permasalahan yang besar sekalipun.

Menurut Walgito (2004:205) di samping keterbukaan dalam komunikasi, komunikasi di dalam keluarga sebaiknya merupakan komunikasi dua arah, yaitu saling memberi dan saling menerima di antara anggota keluarga. Dengan

${ }^{5}$ Hafied Cangara. Pengantar Ilmu Komunikasi. Jakarta. Rajawali Pers, 2012. Hal $22-27$ 
komunikasi dua arah akan terdapat umpan balik, sehingga dengan demikian akan tercipta komunikasi hidup, komunikasi yang dinamis.

Keluarga adalah unit terkecil dari masyarakat terdiri dari kepala keluarga dan beberapa orang yang terkumpul dan tinggal di suatu tempat satu atap dalam keadaan saling ketergantungan. (Nasrul Efendi, 1998). ${ }^{6}$

Peranan ayah sebagai suami dari istri, ayah dari anak-anak dan sebagi pemegang kekuasaan dalam keluarga. Ayah berperan sebagai pemberi nafkah, pendidik, pelindung, dan pemberi rasa aman, sebagai kepala keluarga, sebagai anggota dari kelompok sosialnya serta sebagai anggota masyarakat dari lingkungannya. Peranan ibu : sebagai istri dari suami, ibu dari anak-anak. Ibu mempunyai peranan untuk mengurus rumah tangga, sebagai pengasuh dan pendidik anak-anaknya, pelindung, dan sebagai salah satu kelompok dari peranan sosialnya serta sebagai anggota masyarakat dari lingkungannya, disamping itu juga ibu dapat berperan sebagai pencari nafkah tambahan dalam keluarganya. Peranan anak, anak-anak melaksanakan peranan psiko sosial sesuai dengan tingkat perkembangannya baik fisik, mental, sosial, dan spiritual fungsi pendidikan. Anak merupakan penyempurna dlam keluarga. Seorang anak dianggap sebagai pelengkap keluarga dan sumber kebahagiaan.

\section{Bentuk Bimbingan Orang Tua Terhadap Anak}

Sejak lahir, seorang anak sudah mendapatkan bentuk bimbingan dari oang tuanya. Bimbingan adalah suatu bantuan dari seseorang kepada orang lain untuk mengembangkan kepribadian. Menjadi anak-anak yang sangat bergantung pada orang tua. Sebagai manusia, pada hakikatnya seorang anak mempunyai kepribadian unik yang harus dikembangkan. Tahap-tahap perkembangan seorang anak yaitu tahap usia $0-3$ tahun yaitu apa yang dilakukan anak pada usia ini adalah murni dari orang tuanya. Seorang anak belum mampu berfikir tentang apa yang sedang dan akan dilakukannya, ia hanya berfikir bagaimana berperilaku yang tidak mendapat hukuman melainkan disenangi oleh orang tuanya. Orang tua harus sudah mengajarkan nilai-nilai agama pada anak dalam usia ini, karena perilaku beragama adalah sesuatu yang harus dibiasakan dan ditanamkan sejak dini kepada anak sebagai dasar atau pondasi untuk melakukan segala hal. Pendidikan nilai-nilai tentang agama juga akan membantu anak untuk memelihara fitrahnya sebagai manusia, memlihara jiwa, memelihara akal, memelihara keturunan dan memelihara serta menjaga diri dari mengikuti hawa

\footnotetext{
${ }^{6}$ Pengertian Keluarga. http://www.pengertianahli.com/2013/11/pengertiankeluarga.html, Kamis, 14 mei 2015, Pukul 20.00 WIB.
} 
nafsu. ${ }^{7}$

Pada tahapan usia 3 - 6 tahun, pada masa ini mulai muncul rasa keingintahuan pada anak tentang segala sesuatu. Mereka akan lebih sering bertanya tentang segala hal, baik itu tentang makna benda, tentang perilaku, bahkan tentang dirinya sendiri dan orang tua. Biasanya pada masa ini seorang anak akan bertanya kenapa ia harus melakukan kebiasaan-kebiasaan yang sudah ia jalani, pertanyaan tersebut muncul karena anak mulai dapat berfikir apakah dulu ia hanya melakukan karena meniru dan menjalankan apa yang dikatakan oleh orang tua sedangkan muncul keraguan mengapa anak harus meniru dan menjalankan apa yang dikatakan orang tua tersebut.

Terkadang muncul juga beberapa pertanyaan mematikan dari anak, kebanyakan orang tua seringkali menghindar dari pertanyaan-pertanyaan tersebut. Padahal itu merupakan simbol kecerdasan anak yang mulai muncul dan sepatutnya mendapat respon positif dari orang tua. Namun orang tua juga perlu membatasi jawaban dari pertanyaan-pertanyaan tersebut, artinya tidak harus setiap pertanyaan yang terlontar harus dijawab sesuai dengan aslinya. Sebab pada masa ini anak memang cerdas bertanya namun tidak semua jawaban dapat dicerna dengan baik. Maka dikhawatirkan ketika orang tua memberi jawaban secara fulgar, anak akan menyalahartikan terhadap jawaban yang diberikan tersebut. ${ }^{8}$

Tahap usia 6 - 12 tahun, pada tahapan ini seorang anak mulai mendapat kelompok sosial yang lebih luas selain keluarganya pada masa ini. bukan hanya nilai-nilai dan norma yang mereka dapatkan dari orang tua yang harus mereka jalankan, tapi juga nilai-nilai dan norma dari kelompok sosial mereka, misalnya saja sekolah. Jika sebelumnya seorang anak sudah mendapatkan dasar norma dari orang tuanya, maka dia dengan mudah akan memahami dan menjalankan norma dari kelompok sosialnya. ${ }^{9}$

Tahap remaja, lingkungan kehidupan remaja sangat luas dan bebas. Lebih-lebih pemikiran remaja sulit untuk menerima pendapat orang lain. Sekali saja orang tua lengah dalam memberikan pengawasan kepada remaja, maka bisa berakibat fatal. Namun tidak seperti pada masa kanak-kanak, orang tua tidak perlu lagi memberitahu mana yang baik dan mana yang buruk, karena sebenarnya mereka sudah tahu dan memiliki dasar dari apa yang diajarkan orang tua pada waktu ia masih kanak-kanak.

Tahap dewasa, seorang anak yang telah dewasa mampu mengembangkan sikap, wawasan dan pengamalan nilai-nilai (ajaran) agama. Memperoleh atau

\footnotetext{
7 Syamsu Yusuf dan A. Juntika Nurihsan, Landasan BIMBINGAN\& KONSELING (Bandung: PT Remaja Rosdakarya Offset, 2009), hlm 138

${ }^{8}$ Singgih D. Gunarsa dan Ny. Y. Singgih D. Gunarsa, Op cit., hlm 68

${ }^{9}$ Deassy M. Destiani, Bukan Untuk Dibaca (Solo: PT Era Adicitra Intermedia, 2013), hlm 287
} 
mulai memasuki pekerjaan, memilih pasangan hidup, mulai memasuki peernikahan dan hidup berkeluarga, mengasuh dan mendidik anak, mengelola hidup rumah tangga, memperoleh kemampuan dan kemantaban berkarir, mengambil tanggung jawab atau peran sebagai warga masyarakat serta mencari kelompok sosial yang menyenangkan. ${ }^{10}$

\section{Agama}

Kata "agama" berasal dari bahasa Sanskerta, āgama yang berarti "tradisi" atau "A" berarti tidak; "GAMA" berarti kacau. Sehingga agama berarti tidak kacau. Dapat juga diartikan suatu peraturan yang bertujuan untuk mencapai kehidupan manusia ke arah dan tujuan tertentu. Dilihat dari sudut pandang kebudayaan, agama dapat berarti sebagai hasil dari suatu kebudayaan, dengan kata lain agama diciptakan oleh manusia dengan akal budinya serta dengan adanya kemajuan dan perkembangan budaya tersebut serta peradabanya.

Kata lain untuk menyatakan konsep ini adalah religi yang berasal dari bahasa Latin religio dan berakar pada kata kerja re-ligare yang berarti "mengikat kembali". Maksudnya dengan berreligi, seseorang mengikat dirinya kepada Tuhan. Agama adalah jalan hidup yang harus ditempuh oleh manusia dalam kehidupannya di dunia ini supaya lebih teratur dan mendatangkan kesejahteraan dan keselamatan.

\section{Pernikahan Beda Agama}

Kata nikah berasal dari bahasa arab yang didalam bahasa Indonesia sering diterjemahkan dengan perkawinan. Nikah menurut istilah syariat Islam adalah akad yang menghalalkan pergaulan antara laki - laki dan perempuan yang tidak ada hubungan Mahram sehingga dengan akad tersebut terjadi hak dan kewjiban antara kedua insan.

Menurut Kompilasi Hukum Islam pasal 2 bahwa perkawinan menurut hukum Islam adalah pernikahan, yaitu akad yang sangat kuat atau miitsaaqan gholiidhzan untuk mentaati perintah Allah dan melaksanakannya merupakan ibadah. Perkawinan adalah suatu ikatan lahir dan batin antara seorang pria dengan seorang wanita untuk membentuk suatu keluarga yang kekal. Sedangkan yang dimaksud dengan Hukum Perkawinan adalah hukum yang mengatur mengenai syarat-syarat dan caranya melangsungkan perkawinan, beserta akibatakibat hukum bagi pihak-pihak yang melangsungkan perkawinan tersebut.

Di Indonesia hidup bermacam-macam agama diantaranya Islam, Katolik, Protestan, Hindu, Budha, Konghucu dan kepercayaan terhadap Tuhan Yang

${ }^{10}$ Syamsu Yusuf dan A. Juntika Nurihsan, Op cit., hlm 199 
Maha Esa. Dalam kehidupan masyarakat yang heterogen pemeluk dari agamaagama tersebut hidup rukun dengan penuh toleransi antara pemeluk agama satu dengan agama yang lain. Kondisi ini tidak menutup kemungkinan terjadi perkawinan antara orang-orang yang agamanya berbeda.

Perkawinan antar agama yaitu suatu ikatan perkawinan yang dilakukan oleh orang-orang yang memeluk agama dan kepercayaannya berbeda satu dengan yang lainnya. Maksudnya adalah perkawinan antara dua orang yang berbeda agama dan masing-masing tetap mempertahankan agama yang dianutnya.

Pada umumnya setiap agama melarang umatnya melangsungkan pernikahan dengan umat dari agama lain, jika terjadi demikian si pelaku akan mendapat sanksi baik dari kalangan seagama, keluarga maupun masyarakat.

\section{Aturan Pernikahan Menurut Hukum Negara}

Berdasarkan UU no. 1/1974 pasal 66, maka semua peraturan yang mengatur tentang perkawinan sejauh telah diatur dalam UU no. 1/1974, dinyatakan tidak berlaku lagi. ${ }^{11}$ Mengenai perkawinan beda agama yang dilakukan oleh pasangan calon suami isteri dapat dilihat dalam UU no.1/1974 pada pasal 2 ayat 1 bahwa perkawinan adalah sah apabila dilakukan menurut hukum masing-masing agamanya dan kepercayaanya. Pada pasal 10 PP no.9/1975 dinyatakan bahwa perkawinan baru sah jika dilakukan dihadapan pegawai pencatat dan dihadiri oleh dua orang saksi. Dan tata cara perkawinan dilakukan menurut hukum masing-masing agamanya dan kepercayaanya.

Dalam memahami perkawinan beda agama menurut undangundang perkawinan M. Muhibbudin memiliki tiga penafsiran yang berbeda, ${ }^{12}$ yaitu:

a. Penafsiran yang berpendapat bahwa perkawinan beda agama merupakan suatu pelanggaran terhadap UU no.1/1974 pasal 2 ayat 1 jo pasal 8 f. $^{13}$

b. Bahwa perkawinan antar agama adalah sah dan dapat dilangsungkan, karena telah tercakup dalam perkawinan campuran, dengan argumentasi pada pasal 57 tentang perkawinan campuran yang menitikberatkan pada dua orang yang di Indonesia tunduk pada

\footnotetext{
${ }^{11}$ Untuk perkawinan dan segala sesuatu yang berhubungan dengan perkawinan berdasarkan atas Undang-undang ini, maka dengan berlakunya Undang-undang ini ketentuanketentuan yang diatur dalam Kitab Undang-undang Hukum Perdata (Burgerlijk Wetboek), Ordonansi Perkawinan Indonesia Kristen (Huwelijks Ordonantie Christen Indonesiers S.1933 No. 74), Peraturan Perkawinan Campuran (Regeling op de gemengde Huwelijken S. 1898 No. 158), dan peraturanperaturan lain yang mengatur tentang perkawinan sejauh telah diatur dalam Undangundang ini, dinyatakan tidak berlaku. Pasal 66, UU no.1 Tahun 1974

${ }^{12}$ Menurut M. Muhibuddin, Pegawai Pada Pengadilan Agama Wonosari. http://www.pawonosari. net/asset/nikah_beda_agama.pdf

${ }^{13}$ Mempunyai hubungan yang oleh agamanya atau peraturan lain yang berlaku, dilarang kawin. Pasal 8f, UU no.1 Tahun 1974
} 
hukum yang berlainan, yang berarti pasal ini mengatur perkawinan antara dua orang yang berbeda kewarganegaraan juga mengatur dua orang yang berbeda agama. ${ }^{14}$

c. Bahwa perkawinan antar agama sama sekali tidak diatur dalam UU No. 1/1974, berdasarkan pasal 66 UU No. $1 / 1974{ }^{15}$ maka persoalan perkawinan beda agama dapat merujuk pada peraturan perkawinan campuran, karena belum diatur dalam undang-undang perkawinan.

Seorang guru besar Fakultas Hukum Universitas Indonesia, Prof.Dr. Muhammad Daud Ali (alm.) menjelaskan dalam bukunya yang bejudul "Perkawinan Antar Pemeluk Agama Yang Berbeda". Perkawinan antara orangorang yang berbeda agama adalah penyimpangan dari pola umum perkawinan yang benar menurut hukum agama dan Undang-undang Perkawinan yang berlaku di tanah air kita.

Prof. HM Rasjidi, menteri agama pertama RI, dalam artikelnya di Harian Abadi edisi 20 Agustus 1973, menyorot secara tajam RUU Perkawinan yang dalam pasal 10 ayat (2) disebutkan: "Perbedaan karena kebangsaan, suku, bangsa, negara asal, tempat asal, agama, kepercayaan dan keturunan, tidak merupakan penghalang perkawinan.

Pasal dalam RUU tersebut jelas ingin mengadopsi Deklarasi Universal Hak Asasi Manusia pasal 16 yang menyatakan: "Lelaki dan wanita yang sudah dewasa, tanpa sesuatu pembatasan karena suku, kebangsaan dan agama, mempunyai hak untuk kawin dan membentuk satu keluarga. Mereka mempunyai hak yang sama dengan hubungan dengan perkawinan, selama dalam perkawinan dan dalam soal perceraian.

\section{Kedudukan Anak Dalam Keluarga Menurut UUD}

Kedudukan hukum anak yang lahir dari pasangan pernikahan beda agama ini, kita merujuk pada ketentuan Pasal 42 UUP yang menyebutkan bahwa anak yang sah adalah anak yang dilahirkan dalam atau sebagai akibat perkawinan yang sah. Jadi, anak yang dilahirkan dari perkawinan yang sah yang dilakukan baik di Kantor Urusan Agama (untuk pasangan yang beragama Islam) maupun Kantor Catatan Sipil (untuk pasangan yang beragama selain Islam), maka kedudukan anak tersebut adalah anak yang sah di mata hukum dan memiliki hak dan kewajiban anak dan orang tua seperti tertuang dalam Pasal 45 s.d. Pasal 49 UUP.

Selain itu, orang tua yang berbeda agama juga perlu memperhatikan ketentuan Pasal 42 UU No. 23 Tahun 2002 tentang Perlindungan Anak ("UUPA") yang berbunyi:

(1) Setiap anak mendapat perlindungan untuk beribadah menurut agamanya.

(2) Sebelum anak dapat menentukan pilihannya, agama yang dipeluk

\footnotetext{
14 Yang dimaksud dengan perkawinan campuran dalam Undang-undang ini ialah perkawinan antara dua orang yang di Indonesia tunduk pada hukum yang berlainan, karena perbedaan kewarganegaraan dan salah satu pihak berkewarganegaraan Indonesia. Pasal 57, uu no 1 tahun 1974

${ }^{15}$ Op.cit , UU no.1 Tahun 1974 pasal 66
} 
anak mengikuti agama orang tuanya.

Fatwa MUI melarang perkawinan beda agama. Pada prinsipnya, bukan hanya agama Islam. Semua agama tidak memperbolehkan perkawinan beda agama. Umatnya saja yang mencari-cari peluang. Perkawinannya dianggap tidak sah, dianggap tidak ada perkwianan, tidak ada waris, anaknya juga ikut hubungan hukum dengan ibunya. Meskipun UU tidak memperbolehkan kawin beda agama, tetapi Kantor Catatan Sipil bisa menerima pencatatan perkawinan beda agama yang dilakukan di luar negeri. Pemerintah tdak tegas, seharusnya yang dicatat KCS adalah sesuai dengan hukum Indonesia.

Harapan akan lahirnya keluarga sakinah akan sulit dicapai pasangan suami-istri yang berbeda agama, bagaimana mendidik anak-anak mereka. Seorang anak akan kebingungan untuk mengikuti ayahnya atau ibunya. Perkawinan baru akan langgeng dan tenteram jika terdapat kesesuaian pandangan hidup antar suami dan istri, karena jangankan perbedaan agama, perbedaan budaya, atau bahkan perbedaan tingkat pendidikan antara suami dan istri pun tidak jarang mengakibatkan kegagalan perkawinan.

\section{Masalah Dalam Hubugan Komunikasi Keluarga}

Komunikasi bukan hanya sekedar keterampilan berbicara saja tapi perlu bebera keterampilan lain. Dalam menjalin hubungan komunikasi, tentunya orang tua dan anak akan menemui berbagai permasalahan. Permasalahan pertama adalah yang bersumber dari orang tua. Orang tua adalah pasangan suami dan isteri, dimana ada laki-laki dan perempuan. Perbedaan antara karakter laki-laki dengan perempuan tersebut juga dapat menimbulkan masalah dan mempengaruhi hubungan komunikasi, hal itu dikarenakan sikap serta karakter dari keduanya yang cenderung berbeda.

Berbagai permasalahan tersebut muncul ketika orang tua lengah dalam memberikan pengawasan kepada anak. Kelonggaran dan kebebasan yang diberikan dapat megakibatkan anak mersa memiliki kebebasan untuk bertingkah laku sesuai keinginannya. Sebaliknya, apabila orang tua terlalu rapat dalam memberikan pengawasan maka dapan menjadikan anak yang mudah terpengaruh oleh lingkungan luar karena sifat keingin tahuan yang begitu tinggi. Dan lambat laun anak akan memilih untuk berbaur dengan lingkungan yang mereka anggap lebih nyaman daripada berada dalam sebuah keluarga.

Ketika seorang anak merasa nyaman berada di luar lingkungan keluarga, banyak peluang kejahatan sosial untuk masuk pada diri seorang anak. Jiwa seorang anak yang selalu ingin diterima di lingkungan sosialnya, membuat ia memilih teman yang mempunyai minat yang sama dengan dirinya, dapat mengerti jiwanya dan dapat membuat dia merasa nyaman. ${ }^{16}$ Keadaan seperti ini akan membuat seorang anak semakin jauh dari orang tua dan mulai mengikuti kebiasaan lingkungan sosialnya.

\section{Upaya Mengatasi Masalah Hubungan Komunikasi Keluarga}

Komunikasi orang tua dan anak dikatakan efektif bila kedua belah pihak

\footnotetext{
${ }^{16}$ Soesilowindradini, Op cit., hlm 178
} 
saling dekat, saling memahami, komunikatif dan menyenangkan serta ada keterbukaan untuk menumbuhkan sikap saling percaya. Komunikasi yang efektif dilandasi dengan adanya kepercayaan, keterbukaan, dan dukungan yang positif (motivasi) pada anak, agar anak dapat menerima dengan baik apa yang disampaikan oleh orang tua.

Komunikasi efektif antara orang tua dan anak sangat penting untuk menumbuhkan keakraban. Ketika orang tua bersedia mendengarkan segala informasi dari anak secara aktif, kemampuan anak untuk mengungkapkan perasaan dan masalahnya akan mendapat simulus dan semakin meningkat. Kebutuhan komunikasi ini merupakan kebutuhan vital dalam menjalin hubungan harmonis antara orang tua dan anak.

Orang tualah yang diharapkan anak sebagai teman dalam berkomunikasi, sebab hanya orang tualah yang paling dekat dan dapat mendengar dengan penuh perhatian, menerima dan menanggapi segala bentuk perasaan dan masalah yang dikemukakan oleh seorang anak, sehingga anak tidak lari mencari tempat perlindungan dan orang lain yang dianggap dapat menampung segala beban mereka.

Beberapa hal dapat dijadikan pedoman untuk dapat melaksanakan dan menjalin hubungan komunikasi antara orang tua dengan anak secara baik adalah: Pertama keterbukaan adalah sikap dapat dan bersedia menerima masukan dari yang lain, atau dalam hal ini dari orang tua maupun anak, serta berkenan menyampaikan informasi-informasi yang dianggap penting. Sikap terbuka di antara anggota keluarga akan semakin memperkuat ikatan batin di antara mereka. Kedua empati adalah kemampuan orang tua untuk merasakan apa yang dirasakan oleh anak, dapat memahami suatu persoalan dari sudut pandang yang berbeda melalui kacamata anaknya.

Ketiga yaitu saling mendukung artinya antara orang tua dan anak memiliki komitmen untuk terselenggaranya interaksi secara jujur dan terbuka. Dukungan yang diberikan orang tua kepada anak dapat membuat anak semakin bersemangat dalam hidup dan memunculkan sikap terbuka tekerhadap orang tua. Berpikir positif dan orang tua memberi pengertian kepada anak bahwa antara keduanya memilliki kepentingan, sama-sama bernilai, berhaga, dan saling memerlukan. Di samping itu orang tua juga tidak diperkenankan memaksakan kehendak pribadi yang dapat menyebabkan tidak nyamannya anak ketika akan menyampaikan sesuatu kepada orang tuanya.

\section{PEMBAHASAN}

\section{Peran Komunikasi Dalam Hubungan Anggota Keluarga yang Berbeda Agama}

Peran komunikasi dalam hubungan anggota keluarga yang berbeda agama dalam informan di Kec. Gunung Anyar dinilai kurang efektif karena frekuensi bertemu antar anggota keluarga. Hal ini disebabkan orangtua kurang meluangkan waktu bersama anaknya karena sibuk bekerja. Biasanya anak juga sibuk dengan kegiatan sendiri selain disekolah yaitu les prifat, belajar mengaji dan lainnya.

Kesibukan orang tua yang menghabiskan waktu dari pagi hingga sore dengan bekerja diluar rumah membuat anak merasa terbatasi waktunya untuk 
bertemu orang tua mereka. Apalagi saat orang tua itu dirumah tidak meluangkan waktu sejenak untuk bertemu atau sekedar bertanya kabar anak membuat anak merasa tak dihiraukan. Dengan begitu seolah-olah ada pembatasan antara orang tua dan anak.

Bentuk bimbingan oleh orang tua beda agama terhadap anak sepenuhnya percaya pada Lembaga Pendidikan. Lembaga Pendidikan dianggap dapat memintarkan anaknya, mengerti kekurangan anaknya. Sedangkan orang tua orang tua merasa dirinya tidak menguasai segala ilmu yang ada di lembaga pendidikan, dengan demikian orang tua sangat percaya dengan lembaga pendidikan karena mempunyai fasilitas yang memadai untuk mengembangkan anaknya.

Sedikit yang berbeda dengan orangtua pada umumnya, orang tua yang berbeda agama akan memberikan tauladan pada anaknya dengan cara yang sama seperti orang tua yang lain, namun yang berbeda jika orang tua berbeda agama tersebut memberikan tauladan spiritualnya dengan cara apabila bapaknya mengerjakan agamanya ibunya juga ikut mengajarkan, namun jika ibunya mengajarkan agamanya, bapaknya juga mengikuti, bimbingan dari orangtuanya itu juga didukung oleh masyarakat yang secara tidak langsung juga memberi tauladan kepada anak itu.

Sejatinya seorang anak masih dalam masa kelabilan, yang mana ia seringkali dibuat penasaran oleh hal-hal baru di sekitar lingkungannya. Untuk menanggapi rasa penasarannya tak membuat mereka hanya duduk diam dan melupakan begitu saja apa yang membuatnya bertanya-tanya. Justru dengan begitu membuat anak semakin aktif dan lebih kreatif. Berbagai cara akan mereka lakukan untuk dapat menemukan jawaban dari apa yang menyebabkan anak tersebut penasaran.

Ada juga cara orangtua mengatasi masalah dengan anaknya yang di sebabkan latar belakang agama, Salah satu cara yag digunakan oleh orang tua untuk menghindari masalah dengan anaknya adalah orang tua berusaha untuk memenuhi segala hal yang dibutuhkan oleh anaknya. Sehingga anaknya dapat ter bujuk dengan apa yang telah dipenuhi, dan dia akan lupa atau melupakan segala yang menjadi sebuah masalah. Karena dia sudah merasa terpenuhi apa yang diinginkannya.

Ketika Dua budaya yang berbeda digabungkan dalam sebuah tempat dalam jangka waktu yang panjang, lama kelamaan pasti akan timbul yang namanya konflik-konflik baru yang sukar dipecahkan dikarenakan latar belakang budaya yang berbeda diantara mereka, begitupula dengan dua agama yang berbeda kemudian disatukan dalam sebuah keluarga tentu jelas akan timbul sebuah gap apabila tidak ada kesepakatan secara bersama mengenai norma-norma yang mereka terapkan dalam sebuah keluarga tersebut.

Dalam keluarga ini yang memiliki latar belakang keluarga yang berbeda mereka memiliki kesepakatan bahwasannya ketika ada sebuah masalah yang terjadi diantara orang tua dan anak maka orang tua berini siatif untuk Memberikan Nasehat kepada anaknya, dan juga mengajak berdiskusi secara buka-bukaan. Terus memberikan motivasi terhadap anak, juga meluruskannya, guna menyelesaikan masalah tersebut.

Kemudian mereka mengatasi masalah dengan anaknya dengan cara memunuhi segala hal yang dibutuhkan oleh anaknya. Sehingga anaknya dapat ter 
bujuk dengan apa yang telah dipenuhi, dan dia akan lupa atau melupakan segala yang menjadi sebuah masalah. Karena dia sudah merasa terpenuhi apa yang diinginkannya, sehingga akan terjalin kembali hubungan yang harmonis diantara mereka.

\section{SIMPULAN}

Dari hasil penelitian tentang "Komunikasi Orang Tua dan Anak (Stidi Pada Keluarga Beda Agama di Kec. Gunung Anyar), maka dapat diambil kesimpulan sebagai berikut :

Komunikasi memiliki peran yang sangat penting dalam setiap hubungan, salah satunya adalah hubungan keluarga. Baik pada keluarga yang hidup dalam satu agama maupun yang hidup dengan berbeda agama. Meski sulit menjaga keharmonisan, perbedaan keyakinan tidak memberikan dampak yang begitu besar terhadap keharmonisan sebuah keluarga, jika saling menghargai keyakinan masing-masing. Semakin sering komunikasi terjadi dalam sebuah keluarga, maka hubungan kekeluargaan tersebut akan semakin akrab dan memunculkan saling keterbukaan di antara anggota keluarga. Karena gaya komunikasi yang diberikan oleh orang tua kepada anak dapat memberikan pengaruh pada pola perkembangan pemikiran anak.

Semua orang tua pasti ingin yang terbaik bagi anaknya, tidak terkecuali orang tua yang berbeda agama. Segala bimbingan dan pendidikan diupayakan oleh orang tua agar anaknya bisa meraih cita-cita dan hidup bahagia di masa depan. Orang tua juga memberikan tauladan dan contoh menggunakan sikap yang ditunjukkan orang tua dengan harapan agar anaknya dapat mengerti arti kehidupan dan dapat menjalani hidup bahagia tanpa banyak hambatan. Untuk pendidikan agama, orang tua yang berbeda agama mengenalkan tentang latar belakang agama agar anaknya dapat menentukan sendiri agama yang sesuai dengan kebenaran yang dipercaya anaknya.

Dengan segala fasilitas pendidikan maupun materi yang diberikan oleh orang tua, kadangkala hal itu membuat seorang anak menjadi lebih tertutup dan enggan mencurahkan isi hati dan segala permasalahan yang dia alami di luar rumah. Untuk keluarga yang berbeda agama, perbedaan agama tidak menimbulkan masalah besar. Antisipasi masalah yang dilakukan orang tua beda agama dengan pendidikan forman dan tauladan yang baik, cukup membuat anak bisa menentukan sendiri keyakinan yang akan dipilih pada saat waktunya tiba.

Sama halnya denga keluarga pada umumnya, keluarga beda agama juga memberikan nasehat kepada anakanya saat anaknya berbuat kesalahan. Pembicaraan dari hati ke hati yang diterapkan oleh orang tua dalam mengatasi kenakalan anak, diharapkan dapat lebih mengena di hati anak sehingga anak tidak ingin melakukan kenakalan lagi. Dan untuk menghilangkan rasa kekecewaan atau kemarahan yang kadang terjadi pada anak, tidak jarang orang tua memberikan apapun yang diinginkan oleh anak. Namun hal itu pun tetap dalam batasanbatasan yangsebelumnya telah disepakati oleh orang tua. 


\section{Endnotes}

1. Singgih D. Gunarsa dan Ny. Y. Singgih D. Gunarsa, Psikologi Perkembangan Anak dan Remaja (Jakarta: PT BPK Gunung Mulia, 2006), hlm60

2. Syamsu Yusuf dan A. Juntika Nurihsan, Landasan BIMBINGAN\& KONSELING (Bandung: PT Remaja Rosdakarya Offset, 2009),hlm135

3. Syamsu Yusuf dan A. Juntika Nurihsan, Landasan BIMBINGAN\& KONSELING (Bandung: PT Remaja Rosdakarya Offset, 2009),hlm138

4. Q.S. Ar Rumm :21

5. Hafied Cangara. Pengantar Ilmu Komunikasi. Jakarta. Rajawali Pers, 2012. Hal 22-27

6. Pengertian Keluarga. http://www.pengertianahli.com/2013/11/pengertiankeluarga.html, Kamis, 14 mei 2015, Pukul 20.00 WIB.

7. Syamsu Yusuf dan A. Juntika Nurihsan, Landasan BIMBINGAN\& KONSELING (Bandung: PT Remaja Rosdakarya Offset, 2009), hlm 138

8. Singgih D. Gunarsa dan Ny. Y. Singgih D. Gunarsa, Op cit., hlm 68Deassy M. Destiani, Bukan Untuk Dibaca (Solo: PT Era Adicitra Intermedia, 2013), hlm 287

9. Syamsu Yusuf dan A. Juntika Nurihsan, Op cit., hlm 199

10. Ordonansi Perkawinan Indonesia Kristen (Huwelijks Ordonantie Christen Indonesiers S.1933 No. 74), Peraturan Perkawinan Campuran (Regeling op de gemengde Huwelijken S. 1898 No. 158), dan peraturan-peraturan lain yang mengatur tentang perkawinan sejauh telah diatur dalam Undangundang ini, dinyatakan tidak berlaku. Pasal 66, UU no.1 Tahun 1974

11. M. Muhibuddin, Pegawai Pada Pengadilan Agama Wonosari. http://www.pawonosari. net/asset/nikah_beda_agama.pdf

12. Mempunyai hubungan yang oleh agamanya atau peraturan lain yang berlaku, dilarang kawin. Pasal 8f, UU no.1 Tahun 1974

13. Yang dimaksud dengan perkawinan campuran dalam Undang-undang ini ialah perkawinan antara dua orang yang di Indonesia tunduk pada hukum yang berlainan, karena perbedaan kewarganegaraan dan salah satu pihak berkewarganegaraan Indonesia. Pasal 57, uu no 1 tahun 1974

14. Op.cit, UU no.1 Tahun 1974 pasal 66

15. Soesilowindradini, Op cit., hlm 178

\section{DAFTAR PUSTAKA}

D. Gunarsa, Singgih dan Ny. Y. Singgih D. Gunarsa. 2006.Psikologi Perkembangan Anak dan Remaja. Jakarta: PT BPK Gunung Mulia

Yusuf, Syamsudan A. Juntika Nurihsan. 2009.Landasan BIMBINGAN \& KONSELING. Bandung: PT Remaja Rosdakarya Offset Q.S. ArRumm:21

Sugiono. 2008.Metode Penelitian Pendekatan Kuaitatif kuantitatif. Bandung: 
Alfabeta

Nazar,Ph.D,Moh. 2003.Metode Penelitian. Jakarta :Pt Bhakti Indonesia

J Moelong, Lexy.Metode Penelitian Kulitatif.Bandung :Remaja Rosdakarya

Walgito, Bimo, 2004. Pengantar Psikologi Umum, Andi, Yogyakarta

Mudjiono, Yoyon. 2013.Pengantar Ilmu Komunikasi.Surabaya :Jaudar Pers

Cangara, Hafied. 2012.Pengantar Ilmu Komunikasi. Jakarta. Rajawali Pers

Afandi, Ali. 1997.Hukum Waris, Hukum Keluarga, Hukum Pembuktian. Jakarta, Rineka Cipt

Prawirohamidjojo, R. Soetojo dan Azis Safioedin. 1985.Hukum Orang dan Hukum Keluarga, Bandung : Alumni Kitab undang-undang Hukum Perdatapasal 26

M. Muhibuddin, Pegawai Pada Pengadilan Agama Wonosari Singgih, Gunarsa D., Ny. Y.

Singgih D. Gunarsa. 2006. Psikologi Perkembangan Anak dan Remaja. Jakarta: PT BPK Gunung Mulia

Yusuf, Syamsu., A. Juntika Nurihsan. 2009. Landasan BIMBINGAN\& KONSELING. Bandung: PT Remaja Rosdakarya Offset

Priyatna, Andi. 2012. Ayo Ajarkan Anak Tanggung Jawab Finansial (Jakarta: PT Elex Media Komputindo Kelompok Gramedia

Sumantri, Mulyani., Nana Syaodih. 2010. Perkembangan Peserta Didik. Jakarta: Universitas Terbuka

Destiani, Deassy M.. 2013. Bukan Untuk Dibaca. Solo: PT Era Adicitra Intermedia

Soesilowindradini. tanpa tahun. Psikologi Perkembangan(Masa Remaja). Surabaya: Usana Nasional

\section{WEB}

http://www.pawonosari. net/asset/nikah_beda_agama.pdf

http://id.wikipedia.org/wiki/Kota_Surabaya\#Budaya. Minggu, 10-05-2015. 17.20 
http://dinkominfo.surabaya.go.id/dki.php?hal=30. Minggu, 11-05-2015. 01.15

http://ciptakarya.pu.go.id/profil/profil/barat/jatim/surabaya.pdf. senin 11-05-2015. 12.31

http://www.pengertianahli.com/2013/11/pengertiankeluarga.h tml, Kamis, 14 mei 2015, Pukul 20.00 WIB 